\title{
Subalternity and Insecurity of the Indian Womenfolk Who Have Always Been Marked as Etcetera...
}

\author{
Soumita Nath \\ Department of English, Sarojini Naidu College for Women, Kolkata, India.
}

\begin{abstract}
How to cite this paper: Soumita Nath (2020). Subalternity and Insecurity of the Indian Womenfolk Who Have Always Been Marked as Etcetera... The Educational Review, USA, 4(6), 120-127. DOI: $10.26855 /$ er.2020.06.001
\end{abstract}

Received: April 29, 2020

Accepted: May 28, 2020

Published: June 18, 2020

Corresponding author: Soumita Nath, Department of English, Sarojini Naidu College for Women, Kolkata, India.

Email: soumitanath466@gmail.com

\begin{abstract}
Each time a woman stands up for herself, without knowing it possibly, without claiming it possibly, she stands up for every woman. Because feminism is not about showing that women are powerful. They are already powerful. Feminism is the way to change the perspective of the world how they perceive us to be. Nowadays, there is a common word "women empowerment". What is women's empowerment all about? Is there any rigid theory to empower them? There is a day called "International Women's Day". In this day, men post good things in social media about their wife, daughter, girlfriend etc. Among those men, some of them celebrate women's day every day and some of them just post on that day in social media. Some of them help their ladies in every way possible and some of them rebuke their women if they cannot make their dinner properly for their illness. No, it is not always about the male chauvinists who engulf women's lives. Sometimes, it is they who make wrong choices and suffer. It is very likely to consider someone as culprit but it is very hard to understand and rectify their own mistakes. There have been ups and downs. There have been hurdles and pebbles. Some of them have continued their fight. Some of them could not fight because they did not have that courage. This paper would like to review their struggle from past to present to seek the way how justice is delivered. And the quest is on.
\end{abstract}

\section{Keywords}

Women empowerment, struggle for existence, justice delivered, male chauvinism, women's day celebration irony

\section{Introduction}

It was quite interesting that a few days back I saw a post on social media that a husband is wishing birthday to his wife saying "our caretaker, our homemaker, our nurse, and the motherly figure, I wish you a very happy birthday". And his well-educated wife also felt very much overwhelming for this post. She thought that she was everything in her family and was willing to perform her daily duties happily. Life was going on...

Probably while introducing his wife with others Mr Sharma would say something like this "Meet my wife. She is the queen of my household. You know that she is an awesome cook, she makes delicious food”, etc. Probably his wife was 
an MBA. Her degree was suppressed under the burden of the household. Oh no! I used the word "burden" because his happy homemaker chose to be a happy homemaker on her own.

Life was going on...

There is a day for us on $8^{\text {th }}$ March. That is called “International Women's Day". On this day, men celebrate the contributions of their wives, mothers, sisters, girlfriends, and post on Facebook, Instagram. Some of them celebrate it in their real lives and some of them just post it for "likes". Life is going on...

\section{But What Happened to Them Why Did They Cry for Justice?}

From 1860 to 1945, there was a constant fight of women to establish equality between genders. The madwoman fever began in 1977 by Elaine Showalter and Sandra Guber. Men were ready to mystify women as the weaker sex. Men considered themselves as subjects and women had always been considered as others. Once when Mary Wollstonecraft protested, she was tagged as a "hyena in a petticoat" by her male contemporary. In the feminine phase, they tried to adhere to male values, female writers tried to imitate them, copy them. When they came to the feminist phase in the 1880s they tried to rebel against prevalent patriarchal rules. Ecriture feminism came intending to rescue women from being isolated. They made their original language to fight against injustice. They asked for voting rights, welfare, development, and citizenship and we experienced the suffrage movement.

It had been shameful to feel that throughout history there had been many restrictions placed on the voting rights for commoners respective of age, race, gender, education, and social strata. During the late $19^{\text {th }}$ and early $20^{\text {th }}$ century, men in the UK had the right to vote but women did not have the right to vote. When they were fighting for their own voting rights queen victoria also ridiculed them saying it was going to be a mad, wicked folly despite being a powerful woman herself.

In the late $19^{\text {th }}$ and early $20^{\text {th }}$ centuries, many women started campaigning for their voting rights. At that time, we saw two different groups. One was the National Union of Women's Suffrage Societies and another one was Women's Social and Political Union. The first group was called suffragists and the second one was called suffragettes. Though their tactics were different but somewhere their agenda was the same. They all cried for "voting right for women”. But during World War 1, their roles drastically changed. Society changed their roles. It was the society that always kept women inside the home but World War 1 gave them freedom. Till that time they had been at home for cooking, cleaning, washing, etc., but during World War 1, the patriarchal society asked their hands to run the country. When millions of men had been sent to war their places got vacant, and the country needed women to keep the economy going. They came out of their households and started working in different industries, even in munitions factories to make a weapon for the war.

Women's text had always been palimpsests. Why they always had hidden meanings? Why did not they come with the Ecriture writing years back? The "madwomen theory" came with all the answers lurking in the minds. Would you be able to read Jane Eyre with the effect of madwoman theory in your mind? Would you be able to consider Bertha Mason real and Jane Eyre as an artificial one, trying to adjust the male-dominated patriarchal world? With this approach came Susan Gilbert, Sandra Guber, Helene Cixous, Lucy Irigaray, and Julia Kristeva. Ecriture feminism came to upset the notion of language set by men. Freud himself underestimated in a book that women were suffering from penis envy or lack. They had always been considered as lack. Men had always been the subject and women had always been the "other". Moreover, most of the time women were not seen as national subjects, they have treated the way a religion-based community wants. But we should also admit that issues of white women and the woman of third world countries are not the same. A black woman would find her sisterhood with an Indian or Afghan woman rather with a 
woman residing in America.

Post-colonial feminism came with the notion to reject the idea of mainstream feminism. It expresses its concern and addresses the expression of Chicano, Asian-American women of other cultural and geographical location. The treatment of patriarchy changed according to the colour of the skin. Moreover, in Islamic society feminism came in 1990. In their writings, Islamic nations, religion, and patriarchy have been subject to scrutiny. It had always been considered Islam and patriarchy did not go together. East Asian countries like Afghanistan and Pakistan did not even allow their women to come into contact with the outer world. Afghanistan had probably been the worst one where men were allowed to keep more than one woman according to their needs. They were allowed to torture their wives. They were allowed to marry three or four times and his first wife had to share the room with others. Women had to take the help of any of the male members of the family to go out of their homes, be it a boy of three years; he would be considered the protector of the lady. The independent human rights commission said that the number of cases of violence against women has increased by upto $24.7 \%$ every year. The Taliban made the country hell. They cried for justice. Many of them took daredevil steps to escape from Afghanistan and start a new in some of the other countries. Some got success and some were failed. And who was caught the Taliban executed them? Most of the people were women. We have seen horrible pictures in Kabuliwalar Bangali Bou by Sushmita Banerjee. Some of the residents of Pakistan said that they required female superheroes so that their women got motivated. They would be motivated by seeing them. Pakistan's nearest and dearest superhero "Sarah" had vowed a battle against the officials and tried to protect the oppressed women. She wanted her next generation to fight against inhuman patriarchal laws. Hassan Siddiqui, the maker of "Sarah" told that there was a huge shortage of female role models in this Pakistan society as wells in the mainstream. He wanted to create a strong female character for the girls in Pakistan. Through our study, we got to know that Pakistan's education system is ruined. It was because of the shortage of money. But sometimes it was fully unfunded for decades and they are growing illiterate.

If we look at Afghanistan, thirteen years of the reign of the Taliban gave rise to horror, terrible mental and physical torture, and numerous numbers of bloodshed, rapes, human trafficking. And the victims are mostly women. Your heart cries when you read A Thousand Splendid Suns by Khaled Hosseini when you meet Mariam and Laila. They had been the victims of the Taliban torture in Afghanistan. Men like Rashid were no less than the Taliban but he was their husband. They fought against him, against patriarchal torture and one of them had to end her life for self-defence and the tragic ending of Mariam's lifethat killed her husband for self-defenceas well as to defend Laila, Rashid's second wife. We also feel the same for Rahima. She is the tragic protagonist in the book The Pearl that Broke its Shell by Nadia Hashimi who aptly described the situation of Kabul of that time. Rahima was forced to play the role of "Bacha Posh" to survive in a male-dominated patriarchal society. Though the characters are fictional, the context and content both are real.

\section{Say No to Miss America}

Great American dreams took place there, the American dream was rooted in the declaration of independence. There was a tagline: "All men are created equal”, is not there a smell of gender discrimination? From 1830, American women cried for justice. They were trying to get their voting rights, their voices were always suppressed and they had no active part in deciding where the new country would go. The great American Revolution opened the door for them. Their husbands went to war, and women came out. They got a chance to come to the front. In 1830, they formed national women's league. Till 1920, they got voting right. We experienced a suffrage movement. The great miss America protest held at miss America contest 1969, saying no to fake beauties and they protested by burning their bras, eyelashes, 
beauty products. They threw all into a freedom trash can. They also threw away magazines like playboy or cosmopolitan. They were the instruments of female torture. And there was a tagline: "say no to Miss America" and "all women are beautiful”.

\section{Can We Relate Them With Ourselves?}

"You can tell the status of the nation by looking at the status of women"-Jawaharlal Nehru.

The status of women depicts the social, economic, and mental condition of a nation. In India, either they had been considered as Devi or just a mere object to gaze which arouses sexual fantasy. Either Indian men had put spirituality on them or they had just been treated badly and unequally to men. Social evils such as dowry, sati system, marriage at a very early age were very prevalent at that time. In ancient times, though they were educated but suffered from the evil of society. But a few open-minded educated citizens like Raja Ram Mohan Roy, Ishwar Chandra Vidyasagar, and Swami Vivekananda came forward for the moral upliftment of the society. They wanted to put an end to the evil. Then the practices of sati, child marriage were abolished. Various acts were passed in this direction. After gaining freedom Indian women had distinguished themselves in various spheres of life as politicians, orators, lawyers, doctors, administrators, etc., there was hardly any sphere of life in which they had not taken part. Unlike other foreign countries, our women had voting rights. They even contested in parliaments and assembly.

Some traditions which were to be abolished are still present in your society. One of them is dowry systems. Still, the bride's family gives money, jewellery, and furniture to the groom's family as a token of boon so that they keep their daughters happy and safe. Many marriages are broken just because of this dowry culture. So many cases of suicide and suicidal attempts are prevailing there just because that poor father has been unable to satisfy the greed of the groom's family. Though the dowry system was made illegal in 1961, this tradition is still going on. Sometimes, dowry is also used to achieve economic security and climb a social ladder. Though the Indian constitution gives equal right to men and women still strong patriarchal traditions persists in many different social parts. And a women's life is shaped by those restrictions created by the patriarchal community. Sometimes, women have been considered as a liability when they are at 25 and still not married. People keep on asking questions about her marriage as if they are more bothered than the father of the daughter. The child marriage act is strictly prohibited in India under the prohibition of the child marriage act 2006 but some Indians, living in a rural area are continuing this. According to UNICEF'S state of the world's children 2009 report, 47\% of Indian women aged twenty or twenty-four were married before the legal age of eighteen, with $56 \%$ of rural areas. The report also showed that $40 \%$ of the world's child marriages occur in India.

In India, females are also discriminated against even after marriage. For example, in most cases, if she gives birth to a baby girl she is treated rudely at her Sasural. Even when it is a decision of father's property there is also discrimination if she has a brother. Even when a couple is happy without children in their conjugal life, there is always a question that lurks that when they are having babies. Society is curious if there is any fault in women. And if we look at the cases of marital rape there would be shocking facts. Probably some women are continuously raped in their marriages and as a result, they felt unwanted pregnancy. Society does not look at those. Moreover, we must say that violence against women is mostly present nowadays than it appears to be present at first glance. Many of the acts of violence are even not considered a crime. According to national crime record bureau of India, it reported incidents of crime against women increased by almost 6.5\% during 2012 and in India, a crime against women is committed in every three minutes.

And almost twenty-one dowry deaths per day are reported in the country every day. But the conviction rate is only $34.7 \%$ almost. According to the reports of NCRB stated in 2015 almost seven thousand women died due to dowry 
harassment. Though police have charge-sheeted $94 \%$ cases only $34.7 \%$ have been convicted. Dowry comes from a word dower. It overtly means any kind of presents or gifts given to a bride at the time of marriage. It is expected to be a voluntary act on the part of the parents or well-wishers of the bride to give things for the starting of her new household; the situation is already degraded in India. Previously in this paper, I have already described how girls are always driven by gender inequality and the belief that they are inferior to boys. Child marriages are common in poor families because they often consider their daughters as a burden that can reduce their economic burden when they are married off. And fewer dowries are expected from young brides. They have always been considered as paraya dhan. It overtly means the property of others, someone else's wealth. Probably girls' productive capabilities are more valued than her identity. Instead of going to school, girls often find themselves forced to work to help their families. Thus to educate a daughter was less of a priority than educating sons. And if we talk about household labour, we must say that often girls are married off at puberty because at that time, they are much more productive. Social pressure to marry at an early age is a custom within certain casts. Child marriages are sometimes used to control female sexuality, sanctify sex, and ensure reproduction. Sometimes, family has certain thoughts in mind that the girls should not be corrupted by men of inferior or lower casts so they are more concerned about their virginity rather than their education. The family also fears if they get corrupted for the environment. But nobody thinks about marital rape which is still legalized in India. And most of the time, it is seen that child brides in India are at greater risk of sexual and physical violence at the home of their husbands.

Marital rape is still not a crime in India. The global rape epidemic found that India was one of the only ten out of eighty-two jurisdictions that still legalized marital rape. But the word "rape” itself codified and includes all sorts of sexual assault involving non-consensual intercourse between a husband and a wife. While unwilling sexual contact between a husband and a wife is recognized as a criminal offense in almost every country of the world but here in India is one of those countries that still have not criminalized marital rape. Here a married woman is still not considered as an independent legal entity. Rather she is considered as a possession of her husband.

The status of women in India has been subjected to many great changes over the past few millenniums. But in the early Vedic Periods, they enjoyed equal rights to men. We have heard the names of Gargi, Apala, and Maitreyi but from the 500BC situation got worse with the invasion of Mughal and later on British invaders. The empowerment of women involves many things. It is not always about social equality. It also includes economic opportunity and personal rights too. Women are most of the time-deprived of these human rights, often as a matter of tradition. And in rural areas, they are mainly relegated to household duties and cheap labour. Looking at the society where mainly men control the destiny of women how is it even possible to empower them fully? And most of the time women also feel that they have to fulfill the wishes of their men. Equality comes when both genders are ready to accept and respect each other. Developing women's capacity for income generation without threatening men is the key. We have seen many rural projects but they also have a dismal failure.

In 2012, only $27 \%$ of adult Indian women had a job or were actively looking for one compared to $79 \%$ of men. Almost 20 million women had dropped out of the workforce between 2005 and 2012 and this equivalent to the entire population of Sri Lanka. And according to India's rapid urbanization does not encourage more women to join the labour force. According to the report, India ranks one hundred and twenty among one hundred and thirty-one countries in the female labour participation rate. Women's economic empowerment is highly connected with poverty reduction as women also tend to invest more of their earnings in their children and communities.

There is a saying that when you educate a man, you educate a man but when you educate a woman, you educate a whole nation because a mother is the first teacher for her child. The child learns his first lesson from her mother. If our 
daughters are uneducated, how would they be able to build a nation? They have always driven by gender inequality and the belief that they are inferior to boys. But now the time is changing, here modern time is explicitly concerned with the safety of women. Though there were ups and downs, hurdles but some women have used those as their weapon to make themselves stronger. Indian women have always been the epitome of beauty, strength, and intelligence. Today, when the whole world is celebrating women's power, they also deserve applause and a closer look takes us to the fact that one of the major contributors to Indian society has been the active participation of Indian women in social work as well as in politics. The women activists have played a significant role in changing many social evils and have been a shining beacon of hope.

Aruna Roy is one of the prominent characters who have been excellent at her work. She cleared IAS in 1967 when very few people could think of educating their daughters to get a higher degree. She has been a prominent leader of Mazdoor Kisan Shakti Sangathan. Though she started her career as a teacher, soon she realized that teaching is not the profession she is opting for. In 2005, she played a crucial role in establishing the Right to Information Act. Besides taking rewards for various awards for her services, she is a receiver of Ramon Magsaysay Award for community leadership in 2000 and the Lal Bahadur Shashti National Award for excellence in public Administration in 2010. And Times Magazine considered her as one of the hundred most powerful and influential people across the world. Another name comes with her. She is Medha Patkar. She is an apt example of the social reformer. She turned to be a politician later. Her father took part in the Indian independence movement. And her mother was a member of Swadar. It was an association that helped and supported financially weak women. Medha Patkar is strongly involved in tribal and peasant communities in Maharashtra, Madhya Pradesh, and Gujarat. She has also been a member of Narmada Bachao Andolon. That was to save the river and the people of Gujarat. She has been a brave woman always.

Kiran Bedi, another prominent figure of women empowerment and the first woman to crack the IPS examination in the country. She served her departments with full conviction and has been an active officer for whom the crime against women in Delhi was brought under control. And Kiran Bedi was the first Indian woman to be appointed as a policy advisor to the secretary-general of the united nation in the department of peacekeeping organization.

In the time when we all are trying to rise above all the tortures and backlogs, they are the people who are guiding us over a long time. Arundhuti Roy, another apt example of women's power. She campaigned along with Medha Patkar against the Narmada dam project. She has always been an activist and an active writer who has received the Sahitya Academy award from the Indian academy in 2006. Do we know Laxmi Agarwal? Does she need any introduction? Her face wasburnt in an acid attack by goons. She is now a campaigner with stop acid attacks and a TV host. Shewas attacked in 2005 at the age of fifteen. She has also advocated against acid attacks through gathering 27,000 signatures to curb acid sales. She is also the director of Chhanv foundation, an NGO dedicated to the help of survivors of acid attacks in India. She is the receiver of the 2014 international women of congress by Mitchell Obama. She is also the face of viva and diva, which is promoting all girls to reflect their inner beauty, and the person who helped her to reveal her real story is none other Deepika Padukone. Of course, she is a film actress but at the same time, she is a social worker too. She is the one who tried to portray Laxmi Agarwal in her movie Chhapaak. According to her opinion, this movie is one of the most important movies she has ever worked on. We all are aware of the acid violence in our country but we do not know how frequently it happens. She wants to concentrate to boost up the spirit of the girls to fight back, the film also tells about the number of crimes in our country and also about the harsh reality that the girls have to deal with. Deepika has always been an outspoken feminist. She said "New feminism is not about being aggressive, it about reaches the top yet being soft. It's about being you- feminine, strong, and full of power”. She also lent her support to students who were brutalized in tack protesting against the citizenship bill. And there is Shaheen Mistri, the CEO of 
tech for India. And the founder of Akanksha Foundation, she earned global recognition for her dedication to educational equity. Born in Mumbai she realized that Bombay slum kids do not get access to quality education. They will be treated like nothing in the job market. And she founded the Akanksha education foundation which gives school tutorials to students.

\section{And What Happened to the Next? How Digitalization Has Helped Them?}

It has always been said that women are more active on social media than men. And they tend to be bound into unnecessary conversations than men. Some experts explained when women participate in social networks they can, for instance, upload photos on Instagram, at the same time, they are liking pictures on Facebook and sharing a link on LinkedIn. But men, in contrast, have more linear participation and they are more selective while getting engaged to any conversation. And this is the reason why many brands have the strategies that directly target women to sell their products. It is said that Pinterest and Instagram are feminine while Twitter and YouTube have a mainly masculine audience.

Whatever the scene is, let us focus on a different thing. Let us focus on how social media is active in shaping women's empowerment. Today, technology has a direct impact on women's development and has enabled their voice to reach out and be viewed globally. Google report says it clear that the internet is empowering Indian women with every access to information and helping them to make a more informed decision. Within 10 days of $16^{\text {th }}$ December Delhi gang rape, a Facebook group was created named "Delhi for Women's Safety” and they got immense support and people came forward to give active participation to end such crime. Such groups created in social media are not for gossiping or something like that. That was to support women on a serious note. Internet, coming together with social media has branched out as a new form of media. There are some websites which are primarily focusing on women empowerment. They are also focusing on diverse spheres such as health, knowledge, lifestyle, education, etc. when any incidents happen probably social media is the fastest one to gather all the people from different corners in the world.

Another revolutionary movement was the \#ME TOO movement. This is the movement where girls revealed all their harrowing childhood or teenage experiences like rape, molestation, or sexual harassment. Some were raped when they were at their infancy, learning about good touch and bad touch. It gave women a platform to speak out loud about sexual abuse. This movement also revealed a rift in modern-day feminism between the ethos of individualism and self-sufficiency.

But we should again ask one thing. Is the picture the same for everyone? What is social media also acts as a foil to someone? What does social media cause suicides of innocent girls? Well, take an incident. A couple broke up for a reason, and after a break up, the boy try to convince the girl and when he fails to do it, he threatens to expose all their private pictures in social media. In most of the cases, the girl has committed suicide. Though the incident can be reverse too in most of the cases we have seen, the victim is the girl because her parents made her understand all her pride lays in her vagina and her private parts should not be exposed. And the girl did not have that guts to face the problem and was unable to tell anyone. Take another incident, when a male ego is hurt, we are very much likely to see such comments "men are better than women", "women are like grass, they need to be beaten or cut regularly". And some people are more severe saying "See her dress. She needs to be raped, she arouses attraction." The irony is, it is our society who is continuously feeding these gossipmongers.

The fact is that we are not here to judge who is good or who is bad. All we want to say that when respect comes from both genders a healthy society is made. And sometimes, it is up to women whether they want to fight back or hide their faces somewhere seeing injustice. Sometimes it is not the male partner who tries to dominate women, sometimes it is 
them who themselves willingly try to be under the control of a male. High heels are not comfortable when you walk like a new-born calf. The power division needs to be changed. Power relationship requires a severe change. Little steps will prove to be something bigger someday. There is a tricky fact among Indian society. Indian society has considered some women as good when they are in saree and some are considered to be bad when they are in shirt and jeans so if we do not have unity among ourselves how a society can be established. If we do not support each other how a society can be established? There will be no progress if women lag. The miracle happens when we decide to stand with each other rather than standing against each other. Because the most allusive thing a woman can have is confidence and that comes from unity...

\section{References}

Banerjee, Sushmita. (1995). Kabuliwalar Bangali Bou. Calcutta: Bhasa o Sahitya.

Beauvoir, Simone. (1949). The Second Sex. London: Penguin Books.

Bhattacharya, Rinki. (2004). Behind Closed Doors: Domestic Violence in India. New Delhi: Sage.

Butler, Judith. (1990). Gender Trouble: Feminism and Subversion of Identity. London: Routledge.

Dixon, Annette. (2018). Women in India's economic growth. World bank group, https://www.worldbank.org/en/news/ speech/2018/03/17/women-indias-economic-growth.

Hashimi, Nadia. (2014). The Pearl That Broke Its Shell. New York: HarperCollins publishers.

Hosseini, Khaled. (2007). A Thousand Splendid Suns. New York: Riverhead Books.

Husain, Marziyah. (2016). 10 social reformers who fought to bring change in India. Your Story Media Pvt Ltd, https://yourstory.com/2016/06/women-social-reformers-india.

Mitchel, Juliet. (1971). Woman's Estate. Harmondsworth: Penguin.

Mohanty, C. T. (2003). Under Western Eyes: Feminist Scholarship and Colonial Discourses. Palgrave and Macmillan Journal, 30, 65-85.

Nandal, Vikas. (2014). Status of Women through Ages in Asia. In International Research Journal of Social Sciences, 3, 21-26.

P, Abhishek. (2018). A Critical Analysis of the Status of women in India. In International Journal of Pure and Applied Mathematics, 120, 30-36.

Rich, Adrienne. (1986). Compulsory heterosexuality and lesbian existence. In Blood, Bread, and Poetry. New York: W.W. Norton.

Walker, Alice. (1983). In search of our mother's gardens: womanist prose. San Diego: Harcourt brace Jovanovich. 